Angelos P. Markopoulos, Konstantinos P. Souleles, Athens, Greece

\title{
KNEE IMPLANT STUDY AND EVALUATION WITH AXIOMATIC DESIGN METHOD
}

\begin{abstract}
People from all around the globe get their knees injured every day either because of severe sport accidents or because of simple misstepping. Their lives are about to change drastically and dramatically. The pain and the limitation of their movements becomes an obstacle and treatment with painkillers only postpones the problem. In these cases, medical doctors suggest Total Knee Replacement surgery, in which a knee implant replaces the damaged parts of the human injured knee in order to recover partially or fully the normal motion of the knee and therefore the everyday activities of the person in need. In over 95\% of the patients who underwent a Total Knee Replacement surgery, the pain was overcome in sort amount of time, a high percentage of the kinematics of the knee were brought back to normal, and the patients were able to continue their lives. In this paper, the main purpose is to study the knee mechanics, to deconstruct the kinematics and dynamics of this complex system, to develop a new, ambitious knee implant design for severe accidents, perform simulation tests and evaluate it by the rules of the Axiomatic Design Method.
\end{abstract}

Keywords: knee implant design; Titanium alloy machining; finite element simulation; axiomatic design; biocompatibility.

\section{INTRODUCTION}

There are various kinds of knee implants in the market, today. However, there is always possibility for improvement. Every knee implant design needs to comply with the knee mechanics in order to be effective. More specifically a knee implant design should take under consideration the kinematics and dynamics of the knee, the weight, durability and biocompatibility of the implant, as well as the constraints of the moving parts, the co-operation with the rest of the knee parts that remain neutral, the final cost and the installation during surgery.

The kinematics of the knee are divided in three main motion studies. The bending and extending of the knee, the internal and external rotation and the forward and backward movement. The constraints of these movements are equally important to obviate injuries like ruptures, fractures and dislocations. The dynamics of the knee can be categorized in three segments. Load transferring from the upper part of the leg to the opposite and vice versa, vibration absorption and friction minimization and durability in dynamic loads [1, 2]. All the above constitute the functional requirements of the knee implant design. In Axiomatic Design, the customer needs are converted into functional requirements, which need to be satisfied by the design parameters in the physical world [3,4]. 


\section{DESIGN}

In [2] the designs and the materials used in knee implants are thoroughly described. In this paper a novel approach is described.

The knee implant design was developed using the Solidworks Software. The design consists of two part, the femoral and the tibial, see Figure 1. The material used is Ti-6Al-4V with a ceramic coating for corrosion protection and biocompatibility $[5,6]$.

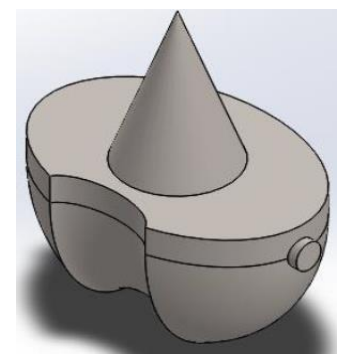

(a)

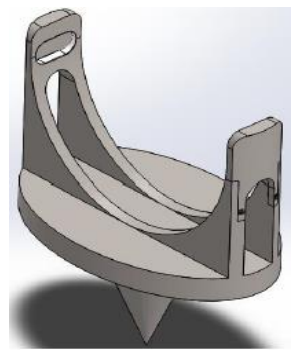

(b)
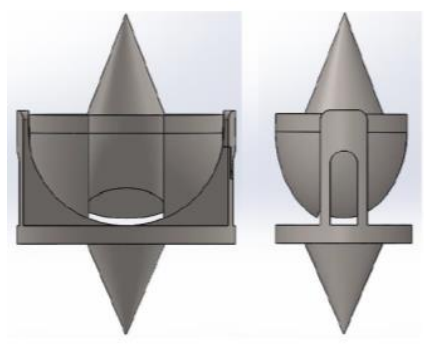

(c)

Figure 1 - (a) Femoral part (b) Tibial part and (c) views of the assembled design

First of all, the femoral part consists of the elliptic, flat surface bounds with the femur so that the implant stays in place and bone cement plays the succorer role, uniting implant and bone. The elliptic shape was given because the femur has also an elliptic section in its lower point. Thus, cutting the lowest part of the femur would leave an elliptic flat surface to match with the implant's upper side, while choosing the specific height to cut provides the opportunity for standardized sizes, lowering the manufacturing cost. Secondly, the conical bulge can be inserted into the femur after a special drilling operation in order to increase the contact surface, hence the stability of the structure. Worth noticing is the difference in contact surface between conical and cylinder bulges. Next comes the patella channel; its purpose is to hold the patella in specific track during the bending and extending movement. The last characteristic of the femur part is the twin side cylindrical column. The two symmetrical cylindrical columns join the femur part with the tibial part conveying loads between them, during everyday activities.

The tibial part bears two symmetrical columns, in the top of which exist two symmetrical slots for the femur part's cylindrical columns to be inserted, see Figure 2(a). In that way the two parts of the implant are connected and cannot be separated. Of course the assembling of these two parts, geometrically could not be achieved if it was not for the separated upper half of one of the two columns of the tibial part. This removing detail, when inserted in its column, according to its 
edged shaped design, leaves only two degrees of freedom that get fixed with two fully thread screws. The symmetrical columns have their bodies machined in the middle, in order to lower the final weight of the design, see Figure 2(b). The tibial part also has the same surface as the femoral part and the same conical bulge to get fixed with the tibia via bone cement.

All the possible and normal movements can be achieved setting the correct boundaries. More specifically the bending and extending of the knee can be achieved when the tibial implant is rotated around the femur implant with the cylindrical column - slot joints to be the axis of rotation. The bending and extension of the knee cannot be modelled as a hinge because the axis of rotation is not stable and the design takes into consideration this unique characteristic [7]. The geometry of the slots are semicircles in distance and include an elastic material to absorb the vibrations and minimize the friction of the cylindrical columns in them. This design provides the possibility the cylindrical columns to move freely into the slots back and forth, up and down, setting different momentarily axis of rotation.

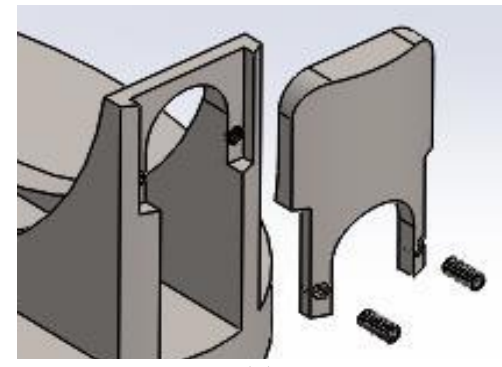

(a)

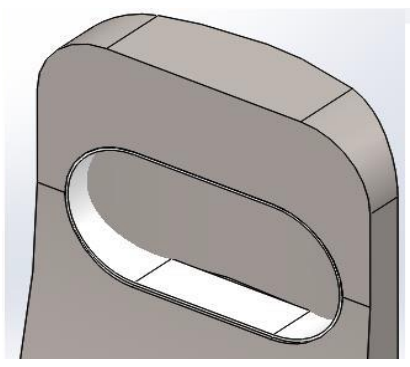

(b)

Figure 2 - (a) Detail in the tibial part and (b) design of the slots

The rest of the movements can also be achieved. While in internal and external rotation, the cylindrical column, can be moved back and forth into the slot in different direction as the opposite twin does. The forward and backward movement is the same situation as before but the cylindrical column moves into the same direction as its twin. Finally, the infinitesimal movement of up and down can be achieved when the two cylindrical columns move into the elastic material of the slots deforming it and taking its place.

The constraints of these movements are set via either the physical structure of the knee system or the geometrically characteristics of the implant design. The upper limit of the extending movement is set by the femur itself, as the patella 
reaches a dead end at its track, while on the opposite direction the limit of the bending movement is set by the end of the patella channel. The constraints of the internal and external rotation of the knee are achieved via the diametrically opposite edges of the tibial part slots while the constraints of the forward and backward movement via the symmetrically edges.

The dynamics of the knee are also satisfied. Load transferring is achieved via the continuous contact of the femoral implant with the tibial implant, vibration absorption and friction minimization via the elastic material in the slots, and the durability of the implant is ensured as the simulations in the next section show.

\section{SIMULATIONS}

The simulation tests were performed in Solidworks software. The material used is Ti-6Al-4V with density $4510 \mathrm{~kg} / \mathrm{m}^{3}$ and yield strength $\mathrm{Sy}=3.7 \times 10^{8} \mathrm{~N} / \mathrm{m}^{2}$. For each of the femoral parts, tibial part and the attachable part of the tibial, two simulations were run. In the first simulation, a $150 \mathrm{~kg}$ person stands still on his leg with the implant on, loading the implant with its bodyweight and in the next simulation, the same person from the same position performs a squat with the same leg, loading the implant with the amount of 7.6 times its bodyweight [8]. The results are shown in Figures 3 and 4.

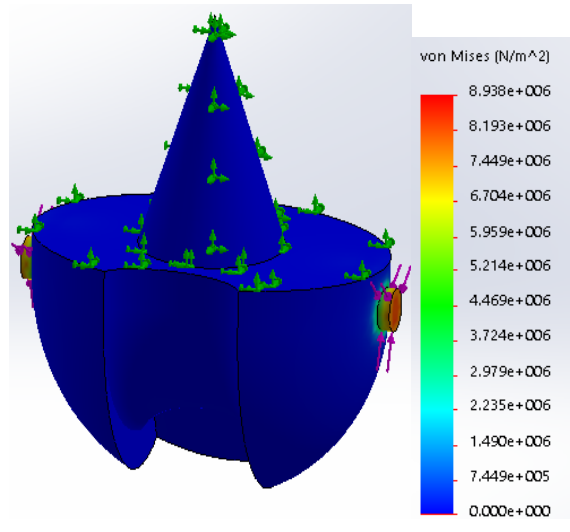

(a)

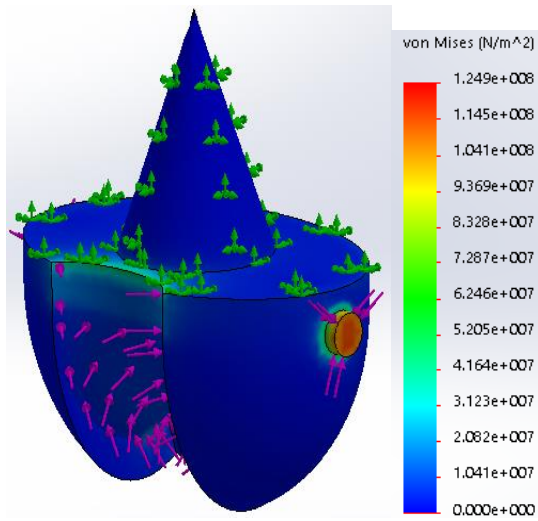

(b)

Figure 3 - (a) First and (b) second simulation on femoral part 
Every simulation result is tabulated in Table 1. All results are acceptable since the applied loads are lower than the yield strength of the implant material.

Table - Simulation Results

\begin{tabular}{|c|c|c|c|}
\cline { 2 - 4 } \multicolumn{1}{c|}{} & \multicolumn{3}{c|}{ Resulting loads $\left[\mathrm{N} / \mathrm{m}^{2}\right]$} \\
\cline { 2 - 4 } & Femoral part & Tibial part & Attachable part \\
\hline $1^{\text {st }}$ Simulation & $8.9 \times 10^{6}$ & $4.3 \times 10^{7}$ & $4.1 \times 10^{7}$ \\
\hline $2^{\text {nd }}$ Simulation & $1.2 \times 10^{8}$ & $3.3 \times 10^{8}$ & $3.1 \times 10^{8}$ \\
\hline
\end{tabular}

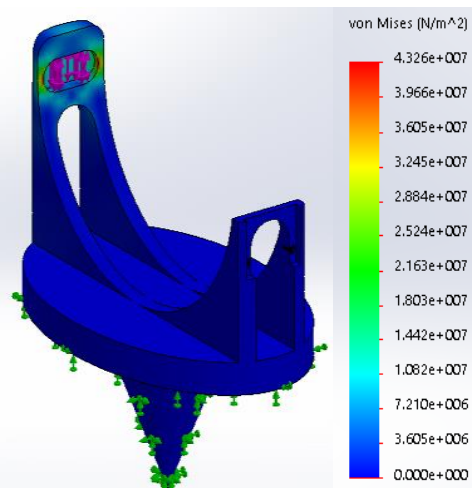

(a)

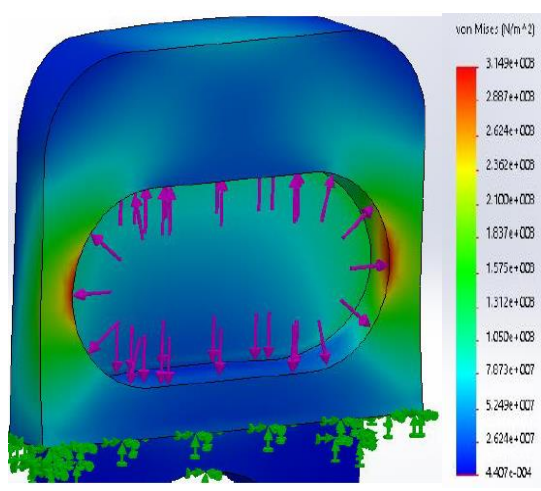

(b)

Figure 4 - Simulation on (a) tibial part and (b) the attachable part

\section{EVALUATION}

Axiomatic Design is a reliable method to design systems and products so that from the very beginning it is possible to know whether a design is going to be successful or not. In this way, methods like trial-and-error, which are time consuming, are set aside. In this paper the Axiomatic Design method is used as an evaluating measure to check if the final design of this knee implant can be characterized as a good design. In order to achieve a good design according to Axiomatic Design, the Design Matrix, consisting of the Functional Requirements (FR) as rows and the Design Parameters (DP) as columns, should be a diagonal matrix or at least a lower triangular matrix. That means that every customer need needs to be satisfied by only one functional requirement and every functional requirement should be achieved by only one design parameter. The second part of 
the above statement can be approved even if the design matrix is not a diagonal matrix but lower triangular matrix. The design parameters set by this paper's design should match the functional requirements of the knee, see Figure 5. The design parameters of the implant's design are shown in Figure 6.

FR1 = Biocompatibility

FR2 $=$ Weight

FR3 = Kinematics

FR3.1 $=$ Bending \& Extension

FR3.2 = Internal \& External Rotation

FR3.3 = Forward \& Backward Movement

FR4 $=$ Restraints

FR4.1 = Upper patella's limit

FR4.2 = Lower patella's limit

FR4.3 = Internal \& External Rotation Limit

FR4.4 = Forward \& Backward Movement Limit

FR5 = Dynamics

FR5.1 = Load Transferring

FR5.2 = Vibration absorption and Friction minimization

FR5.3 = Durability

FR6 $=$ Good collaboration with the rest of the knee parts

FR6.1 = Connection with bones

FR6.2 $=$ Patella's right track

FR6.3 = Find required space for implant to fit

FR7 $=$ Cost

FR8 = Easy installation during surgery

Figure 5 - Functional Requirements

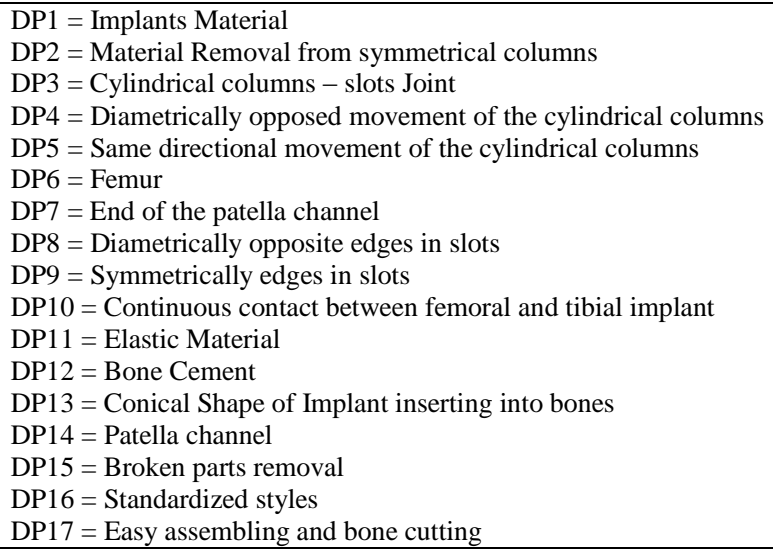

Figure 6 - Design Parameters 


\section{RESULTS AND DISCUSSION}

The design matrix of these FR-DP is shown in Figure 7(a). The Design Matrix in this form cannot provide understandable results for whether the matrix is a lower triangular matrix or not, but for sure the DM is not a diagonal matrix. Making the necessary changes of rows and columns, moving row FR5.3 up top and column DP11 in the second column, provides clear information that the DM is a lower triangular matrix, see Figure 7(b). Blue cells are the diagonal cells, green cells are the non-problematic cells and red cells are the problematic ones.

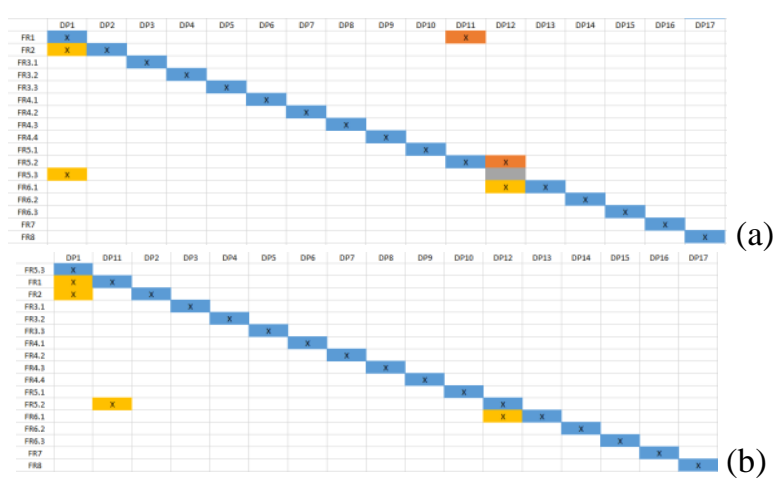

Figure 7 - Design Matrix (a) before and (b) after transformation

According to the Axiomatic Design Method, since the DM is lower triangular and the first axiom, the Independence Axiom is satisfied, this paper's knee implant design can be characterized as a good design.

\section{SUMMARY}

A new design for knee implant was developed based on the knee mechanics. Simulations showed that the durability of the implant is high and can withstand extraordinary loads. Axiomatic Design Method evaluated the implant as a good design. The developed design is in primary stages and needs improvement. However, the concept's basis is strong and it may influence other designs in the future.

References: 1. D. Granchi, E. Cenni, D. Tigani, G. Trisolino, N. Baldini, A. Giunti. Sensitivity to implant materials in patients with total knee arthroplasties. Biomaterials 29(10), 2008, pp. 1494-1500. 2. A.P. Markopoulos, N.I. Galanis, N.E. Karkalos and D.E. Manolakos. Precision CNC machining of femoral component of knee implant: A case study. Machines 6(1), 2018, 10. 3. A.M. Farid, N.P. Suh. Axiomatic Design in Large Systems: Complex Products, Buildings and Manufacturing Systems. Springer, 2016. 4. N.P. Suh. Axiomatic Design: Advances and Applications. Oxford University Press, 
2001. 5. C. Sella, J.C. Martin, J. Lecoeur, J.P. Bellier, M.F. Harmand, A. Naji, J.P. Davidas, A. Le Chanu. Corrosion protection of metal implants by hard biocompatible ceramic coatings deposited by radio-frequency sputtering, Clinical Materials 5(2-4), 1990, pp. 297-307. 6. J.P. Sharkany, M.J. Sichka, A.M. Potapchuk, I.S. Lemko, J.L. Pintye. Biocompatible gradient ceramic coatings for metal implants. Proc. SPIE 4336, Nondestructive Evaluation of Materials and Composites V, 2001. 7. Y. Jun. Morphological analysis of the human knee joint for creating custom-made implant models. International Journal of Advanced Manufacturing Technology 52(9-12), 2011, pp. 841-853. 8. N. J. Dahlkvist, P. Mayo, B.B. Seedhom. Forces during squatting and rising from a deep squat. Engineering in Medicine, 11(2), 1982, pp. 69-76.

\title{
Ангелос Маркопулос, Константинос Р. Сулеліс, Афіни, Греція \\ ВИВЧЕННЯ МЕХАНІКИ КОЛІННОГО ІМПЛАНТУ ТА АНАЛІЗ МЕТОДОМ АКСІОМАТИЧНОГО ПРОЕКТУВАННЯ
}

\begin{abstract}
Анотація. Люди у всьому світі щодня отримують травми колін з-за серйозних спортивних подій або через простої помилки. Їх життя драматично різко і радикально змінюється. Біль $i$ обмеження їх рухів стають перешкодою, і лікування знеболюючими лише відкладає вирішення проблеми. У цих випадках лікарі рекомендують операцію з повної заміни колінного суглоба, при якій імплантант колінного суглоба замінює пошкоджені частини коліна людини, щуоб частково або повністю відновити нормальний рух колінного суглоба $і$, отже, повсякденну діяльність потребує від людини. Більш ніж у 95\% пацієнтів, які перенесли операцію з повної заміни колінного суглоба, біль була подолана за деякий час, високий відсоток кінематики колінного суглоба був повернений, і пацієнти змогли продовжсти активне життя. У цій статті основна мета полягає в тому, щоб вивчити механіку колінного суглоба, розібрати кінематику і динаміку иієї складної системи, розробити новий амбітний дизайн імплантанта колінного суглоба для важких аварій, виконати імітаційні тести і оцінити його за правилами аксіоматичного методу проектування. Аксіоматичне проектування є надійним методом для проектування систем $i$ продуктів, так щзо з самого початку можна дізнатися, чи буде дизайн успішним чи ні. Таким чином, відміняються такі методи, як метод спроб та помилок, які вимагають багато часу. $B$ даній роботі метод аксіоматичного проектування використовується як міра оцінки, щоб перевірити, чи можна охарактеризувати остаточну конструкиію цุього колінного імплантанту як хорошу конструкцію. Для того, щуоб досягти гарної конструкції відповідно до аксіоматичного проектування, матричя проектування, ще складається з функиіональних вимог як рядків $i$ конструктивних параметрів у вигляді стовпџів, повинна бути діагональною матрицею або принаймні нижньою трикутною матрицею.
\end{abstract}

Ключові слова: конструювання колінного імплантату; механічна обробка титанових сплавів; моделювання методом кінцевих елементів; аксіоматичне моделювання; біосумісність. 